\title{
Karakterisasi Nitroselulosa dari Pulp Larut Bambu Beema dan Bambu Industri
}

\author{
Frederikus Tunjung Seta*, Susi Sugesty, Reynaldo Biantoro \\ Balai Besar Pulp dan Kertas, Jl. Raya Dayeuhkolot no.132, Bandung 40258, Indonesia
}

Diterima : 07 Agustus 2018, Revisi akhir : 19 Juni 2019, Disetujui terbit : 25 Juni 2019

\author{
Characterization of Nitrocellulose from Beema Bamboo and Industrial Bamboo \\ Dissolving Pulp
}

\begin{abstract}
Currently, Indonesia still relies on imports of nitrocellulose as a propellant raw material. The objective of this research is to determine the optimum composition of nitrocellulose making for propellant from Beema bamboo pulp and Industrial bamboo pulp as an alternative of dissolving pulp from wood. Prior to the nitration process, both dissolving pulp of Beema bamboo and industrial undergo a pretreatment process using willey mill, the pulp then sieved and taken with a size less than 60 mesh. In the nitration process, the chemical composition used is formula 1 ( $\mathrm{HNO}_{3}: \mathrm{HNO}_{3}$ Fuming: $\mathrm{H}_{2} \mathrm{SO}_{4}=2.5: 1: 9.5$ ), formula $2\left(\mathrm{HNO}_{3}: \mathrm{HNO}_{3}\right.$ Fuming: $\left.\mathrm{H}_{2} \mathrm{SO}_{4}=3: 1: 7,5\right)$ and the formula $3\left(\mathrm{HNO}_{3}: \mathrm{HNO}_{3}\right.$ Fuming: $\mathrm{H}_{2} \mathrm{SO}_{4}$ $=1: 1: 1,6)$. Result showed that dissolving pulp from Beema bamboo with third formula get the highest nitrogen content (12,97\%). Fourier-transform infrared spectroscopy (FTIR) analysis showed that all of the nitrocellulose have nitro group and on the burning test also proved that nitrocellulose can be rapidly burned. However, the solubility of nitrocellulose in acetone and ethers-alcohols indicates that the distribution of nitrogen content in the nitration process is not meet the standard yet.
\end{abstract}

Keywords: bamboo, nitrogen content, nitrocellulose, dissolving pulp, propellant

\begin{abstract}
Abstrak
Saat ini Indonesia masih mengandalkan impor nitroselulosa sebagai bahan baku propelan. Tujuan penelitian ini adalah mencari komposisi optimum pembuatan nitroselulosa untuk propelan dari bahan baku pulp larut bambu Beema dan Industri sebagai alternatif dari pulp larut kayu. Sebelum proses nitrasi, pulp larut bambu Beema dan bambu Industri mengalami proses perlakuan awal dengan menggunakan willey mill, pulp larut kemudian diayak dan diambil pulp dengan ukuran kurang dari 60 mesh. Pada proses nitrasi, perbandingan bahan kimia yang digunakan adalah formula $1\left(\mathrm{HNO}_{3}: \mathrm{HNO}_{3}\right.$ Fuming: $\left.\mathrm{H}_{2} \mathrm{SO}_{4}=2,5: 1: 9,5\right)$, formula $2\left(\mathrm{HNO}_{3}: \mathrm{HNO}_{3}\right.$ Fuming: $\left.\mathrm{H}_{2} \mathrm{SO}_{4}=3: 1: 7,5\right)$, dan formula 3 $\left(\mathrm{HNO}_{3}: \mathrm{HNO}_{3}\right.$ Fuming: $\left.\mathrm{H}_{2} \mathrm{SO}_{4}=1: 1: 1,6\right)$. Hasil yang didapatkan pada penelitian ini pulp larut dari bahan baku bambu Beema dengan formula 3 mampu mendapatkan kadar nitrogen tertinggi (12,97\%). Analisis Fourier-transform infrared spectroscopy (FTIR) menunjukkan adanya gugus nitro dan pada uji bakar juga menunjukkan bahwa nitroselulosa dapat terbakar dengan cepat. Akan tetapi, nilai kelarutan dalam aseton dan eter-alkohol nitroselulosa dari kedua jenis bambu menunjukkan bahwa distribusi kadar nitrogen pada proses nitrasi masih belum memenuhi standar.
\end{abstract}

Kata kunci: bambu, kadar nitrogen, nitroselulosa, pulp larut, propelan 


\section{Pendahuluan}

Nitroselulosa adalah reaksi antara selulosa dan asam nitrat dengan katalis asam sulfat. Nitroselulosa mempunyai rumus molekul $\left(\mathrm{C}_{6} \mathrm{H}_{7} \mathrm{O}_{2}(\mathrm{OH})_{3}\right)_{\mathrm{n}}$, dimana unsur $\mathrm{C}$ dan $\mathrm{H}$ bergabung dengan unsur $\mathrm{O}$ membentuk senyawa yang mudah terbakar apabila terkena energi aktivasi (Pramunditta et al., 2012). Nitroselulosa tidak larut dalam air tetapi larut dalam pelarut organik seperti metanol, aseton, asam asetat glasial, mempunyai berat molekul (BM) 459,28 - 594,28, derajat polimerisasi $(\mathrm{DP})=100-3500$, titik didih $150-170^{\circ} \mathrm{C}$, dan mempunyai berbagai macam bentuk, dari serat berwarna putih sampai larutan yang kental (Kim, 2014; Seta, Sugesty and Kardiansyah, 2014).

Nitroselulosa dapat dibedakan menjadi dua jenis berdasarkan kandungan nitrogen di dalamnya. Nitroselulosa dengan kadar nitrogen di atas $12,75 \%$ disebut juga sebagai Propelant Nitro Cellulose (PNC) dan nitroselulosa dengan kadar nitrogen lebih kecil dari 12,75\% atau disebut juga Industrial Nitro Cellulose (INC).

PNC digunakan sebagai isian amunisi proyektil kecil, sedang, dan besar. Kebutuhan PNC di Indonesia saat ini masih dipenuhi seluruhnya dari impor. JumLah PNC yang diimpor Indonesia pada tahun 2002 sebesar 18 ton dan pada tahun 2006 meningkat menjadi 46 ton (Saragih, Padil and Yelmida, 2014) dan diperkirakan kebutuhan saat ini mencapai 400-600 ton/tahun (Wibowo, 2007). INC dapat digunakan sebagai bahan baku di industri tinta percetakan, adhesif, dan pelapisan pada kulit, kertas, kayu, logam, plastik untuk mendapatkan beberapa sifat spesifik (Fallah, Khorasani and Ebrahimi, 2018).

Selain kandungan nitrogen, karakterisasi nitroselulosa meliputi kelarutan dalam aseton dan ketidaklarutan dalam eter-alkohol (Vogelsanger and Sopranetti, 2010). Penggunaan nitroselulosa sebagai guncotton dengan kadarnitrogen lebih dari $13 \%$ memiliki sifat larut dalam aseton, sedangkan untuk nitroselulosa dengan kadar $10-12,9 \%$ memiliki sifat larut dalam aseton dan eteralkohol. Nilai ketidaklarutan nitroselulosa dalam aseton dan eter-alkohol dapat diklasifikasikan sesuai Tabel 1.

Nitroselulosa dapat dibuat dari berbagai jenis bahan baku, akan tetapi agar hasilnya maksimal, bahan baku yang dipilih harus memiliki kandungan selulosa yang tinggi. Bahan dengan kandungan selulosa yang paling tinggi adalah kapas (hampir
Tabel 1. Klasifikasi Nitroselulosa Guncotton

\begin{tabular}{clcc}
\hline No. & Parameter & Nilai & Kriteria \\
\hline 1. & Kelarutan dalam & $>99,95 \%$ & excellent \\
& Aseton & $99,8-99,5 \%$ & good \\
& & $<99,8 \%$ & marginal \\
2. & Ketidaklarutan & $<5 \%$ & excellent \\
& dalam Eter-Al- & $5-7 \%$ & good \\
& kohol & $<7 \%$ & marginal \\
\hline
\end{tabular}

100\%) (Chen, 2014). Akan tetapi ketersediaan kapas saat ini masih sangat terbatas di Indonesia, sehingga kebutuhan selulosa diharapkan dapat dipenuhi dengan produksi pulp larut.

Pulp larut adalah pulp yang memiliki kandungan selulosa tinggi hampir menyamai kapas dan digunakan untuk pembuatan produk turunan selulosa, seperti serat atau film (viskosa, lyocell), selulosa ester (asetat, propionat, butirat, nitrat), dan selulosa ester (karboksimetil, etil, metil selulosa) (Seta, Sugesty and Kardiansyah, 2014). Bahan baku pulp larut dapat berasal dari hardwood, softwood, dan campuran hardwoodsoftwood. Proses pembuatan pulp larut juga dapat melalui proses pre hidrolisa kraft (PHK) maupun sulfit (Patrick, 2011). Spesifikasi pulp larut (dalam hal ini pulp rayon) di Indonesia harus sesuai SNI 938:2017 - Pulp Rayon, diantaranya harus mempunyai selulosa alfa di atas 94\%, derajat cerah di atas $88 \%$ ISO, viskositas intrinsik di atas $370 \mathrm{~mL} / \mathrm{g}$.

Selain digunakan untuk pembuatan nitroselulosa dan selulosa asetat, sebagian besar produksi pulp larut di dunia digunakan sebagai bahan baku serat rayon (Granström, 2009). Pulp larut juga dapat dibuat menjadi beberapa produk diantaranya selulosa ester (contohnya selulosa nitrat, selulosa asetat), selulosa eter (contohnya $\mathrm{CMC}$ ), dan produk lain berbasis selulosa (contohnya nanoselulosa, mikroselulosa) (Chen et al., 2016). Bahan baku pulp larut selama ini masih mengandalkan impor, terutama untuk serat panjang. Salah satu jenis sumber serat panjang adalah bambu yang banyak ditanam di kawasan hutan rakyat. Bahan baku tersebut banyak dijumpai dan potensinya sangat besar.

Tinjauan morfologis terhadap serat bambu menunjukkan bahwa serat ini layak untuk dibuat pulp larut, walaupun masih ada kendala terhadap kualitas yang dihasilkannya seperti masih tingginya kandungan pentosan, abu, dan 
rendahnya viskositas, hal ini kemungkinan akan berdampak pada kualitas pulp larut yang dihasilkan. Panjang serat bambu rata-rata berkisar antara 2,3-4,4 mm, termasuk ke dalam serat panjang dan lebih panjang dari serat kayu pinus yang mempunyai panjang rata-rata $2,7 \mathrm{~mm}$ (Sugesty, 2014).

Pembuatan nitroselulosa pada penelitian ini menggunakan bahan baku dari pulp larut dari bambu beema (Dendrocalamus beecheyana) dan industri (Mixed bamboo). Penelitian ini merupakan lanjutan dari penelitian yang dilakukan oleh Sugesty (2014). Pada penelitian tersebut pulp larut dari bahan baku bambu Beema dan bambu Industri telah berhasil memenuhi spesifikasi SNI 0938:2010 - Pulp Rayon (Sugesty, 2014; Sugesty, Kardiansyah and Hardiani, 2015).

Penelitian sebelumnya memanfaatkan limbah kelapa sawit dapat menghasilkan nitroselulosa dengan kadar nitrogen 12,75\% (Miranda and Fani, 2013), penelitian lain juga mampu menghasilkan nitroselulosa dengan kadar lebih dari 12\% dengan bahan baku pelepah kelapa sawit (Saragih, Padil and Yelmida, 2014). Analisis kelarutan nitroselulosa belum dilakukan pada penelitian tersebut, padahal analisis kelarutan nitroselulosa sangat penting untuk menggambarkan baik atau tidaknya proses nitrasi. Sedangkan Pramunditta et al. (2012) membuat nitroselulosa dari bahan baku kapas, dan bisa menghasilkan nitroselulosa di atas $12,5 \%$, akan tetapi kapas belum bisa menunjang bahan baku industri propelan dikarenakan ketersediaan kapas di Indonesia masih terbatas dan harganya mahal, sehingga keberlangsungan produksi nitroselulosa terkendala jika dijadikan industri (https://kemenperin.go.id (Indonesia Kurang Bahan Baku Tekstil)). Keunggulan penggunaan bambu dibandingkan dengan kedua bahan baku tersebut adalah ketersediaannya yang melimpah di Indonesia (terutama bambu Gombong dan Beema) dan mempunyai karakteristik yang hampir mirip dengan pulp larut dari kayu. Tujuan penelitian ini adalah menentukan komposisi optimum pembuatan nitroselulosa dari bahan baku pulp larut bambu Beema dan Industri.

\section{Bahan dan Metode}

Penelitian ini dilaksanakan di laboratorium Derivat Selulosa Balai Besar Pulp dan Kertas, Bandung. Bahan baku yang digunakan adalah pulp larut dari bambu Beema (Bambusa balcooa) dan bambu Industri (mixed bamboo). Pulp larut kedua jenis bambu dibuat di laboratorium Pemasakan dan Pemutihan Balai Besar Pulp dan Kertas, Bandung. Kondisi pemasakan dan pemutihan kedua jenis bambu sesuai dengan kondisi yang telah didapat oleh Sugesty (2014). Komponen kimia pulp larut dianalisis dengan metode yang terdapat di Tabel 2. Analisis tiap parameter dilakukan secara duplo.

Tahapan pembuatan nitroselulosa diawali dengan preparasi bahan baku kemudian dilanjutkan dengan proses nitrasi, after treatment, dan penyimpanan nitroselulosa. Preparasi bahan baku terdiri dari mengubah ukuran pulp larut dengan menggunakan alat Willey Mill, kemudian diambil yang lolos ayakan Sieve Shaker 60 mesh. Setelah didapatkan ukuran tersebut, pulp larut dikeringkan dalam oven sampai kering.

Proses nitrasi menggunakan reagen asam nitrat $65 \%$, asam nitrat fuming, dan asam sulfat sebagai katalis. Perbandingan reagen yang digunakan dapat dilihat pada Tabel 3. Pembuatan nitroselulosa sesuai dengan tahapan yang telah dilakukan pada penelitian sebelumnya (Seta, Sugesty and Kardiansyah, 2014).

Tabel 2. Metode Analisis Komponen Kimia Pulp Larut

\begin{tabular}{|c|c|c|}
\hline No. & Parameter & Metode \\
\hline 1. & Kadar Abu & $\begin{array}{l}\text { SNI ISO 2144:2010- } \\
\text { Kertas, Karton dan Pulp- } \\
\text { Cara Uji Kadar Abu pada } \\
900^{\circ} \mathrm{C}\end{array}$ \\
\hline 2. & Kadar Air & $\begin{array}{l}\text { SNI 08-7070-2005 - Cara } \\
\text { Uji Kadar Air Pulp dan } \\
\text { Kayu dengan metode } \\
\text { Pemanasan dalam Oven }\end{array}$ \\
\hline 3. & Selulosa alfa & $\begin{array}{l}\text { SNI 8400:2017- } \\
\text { alfa, beta dan gamma } \\
\text { dalam pulp }\end{array}$ \\
\hline 4. & Viskositas pulp & $\begin{array}{l}\text { SNI 8402:2017 - Viskositas } \\
\text { pulp (metode viskometer } \\
\text { kapiler) }\end{array}$ \\
\hline 5. & $\begin{array}{l}\text { Viskositas } \\
\text { intrinsik }\end{array}$ & $\begin{array}{l}\text { SNI ISO 5351:2012 - } \\
\text { Pulp-Cara Uji Bilangan } \\
\text { Viskositas Limit(Viskositas } \\
\text { Intrinsik) dalam Larutan } \\
\text { Kuprietilendiamina (CED) }\end{array}$ \\
\hline 6. & $\mathrm{~S}_{10}, \mathrm{~S}_{18}$ & $\begin{array}{l}\text { SNI ISO 692:2010- Pulp - } \\
\text { Cara Uji Kelarutan dalam } \\
\text { Alkali }\end{array}$ \\
\hline
\end{tabular}


Tabel 3. Perbandingan Reagen Pembuatan Nitroselulosa

\begin{tabular}{lccc}
\hline & \multicolumn{3}{c}{ Perbandingan Reagen } \\
\cline { 2 - 4 } Formula & $\mathrm{HNO}_{3}$ & $\mathrm{HNO}_{3}$ & $\mathrm{H}_{2} \mathrm{SO}_{4}$ \\
\hline 1 & $65 \%$ & Fuming & 9,5 \\
2 & 2,5 & 1 & 7,5 \\
3 & 3 & 1 & 1,6 \\
\hline
\end{tabular}

Setelah selesai proses nitrasi, nitroselulosa yang dihasilkan disimpan dalam botol berwarna gelap dan direndam dalam alkohol, sedangkan nitroselulosa yang akan dikarakterisasi, dikeringkan dalam suhu udara $20^{\circ} \mathrm{C}$.

Karakterisasi nitroselulosa meliputi kadar nitrogen, uji FTIR, uji bakar, dan ketidaklarutan dalam aseton dan eter-alkohol (Vogelsanger and Sopranetti, 2010). Analisis kadar nitrogen menggunakan metode mikrokjedahl. Peralatan untuk proses digestasi dan destilasi menggunakan VELP UDK-149, sedangkan untuk titrasi menggunakan titrasi manual dengan indikator Tashiro. Uji FTIR dilakukan di laboratorium kimia analitik ITB untuk melihat gugus fungsi Nitrat dalam selulosa. Ketidaklarutan dalam aseton dilakukan dengan menimbang 1 gram nitroselulosa, kemudian dibasahi dengan etanol sebanyak $10 \mathrm{~mL}$, dan diaduk dalam $150 \mathrm{~mL}$ aseton selama 30 menit. Larutan tersebut disaring dengan gooch yang berisi kertas saring Whatman 934-AH dan aluminium oksida. Gooch dipanaskan dalam oven bersuhu $105^{\circ} \mathrm{C}$ selama 45 menit. Prosedur analisis ketidaklarutan dalam eter-alkohol dilakukan dengan cara mencampurkan 2 gram nitroselulosa kering dan $75 \mathrm{~mL}$ etil alkohol kemudian diaduk selama 30 menit. Setelah pengadukan, ditambah $150 \mathrm{~mL}$ eter dan diaduk lagi. Larutan tersebut didiamkan selama 45 menit di dalam lemari es. Dari larutan tersebut diambil $50 \mathrm{~mL}$ dan ditambah $20 \mathrm{~mL}$ aquades kemudian diaduk. Campuran tersebut dimasukkan ke dalam oven bersuhu $105^{\circ} \mathrm{C}$ selama 30 menit.

Ujibakarnitroselulosa dilakukan untuk melihat perbedaan dengan pulp larut sebelum nitrasi dilakukan dengan cara mengontak/melekatkan sejumLah nitroselulosa kering dengan sumber api dan dilihat apakah nitroselulosa tersebut dapat terbakar dengan singkat dan tanpa meninggalkan abu (Seta, Sugesty and Kardiansyah, 2014).

\section{Hasil dan Pembahasan}

\section{Analisis Kimia Pulp Larut}

Analisis kimia pulp larut Bambu Beema dan Bambu Industri dapat dilihat pada Tabel 4. Dari tabel tersebut dapat dilihat semua parameter SNI 938:2017 - Pulp Rayon dapat dipenuhi oleh pulp larut kedua jenis bambu.

\section{Hasil Analisis Kadar Nitrogen}

Pada Tabel5 dapatdilihatrata-ratahasil analisis kadar nitrogen dari kedua jenis nitroselulosa menggunakan tiga perbandingan formula. Kadar nitrogen yang paling tinggi dihasilkan oleh nitroselulosa bambu Beema dengan formula 3 . Secara umum kadar nitrogen nitroselulosa bambu Beema lebih tinggi dari bambu Industri,

Tabel 4. Hasil Analisis Kimia Pulp Larut

\begin{tabular}{lcccc}
\hline Parameter & Unit & $\begin{array}{c}\text { SNI 938:2017 } \\
\text { Pulp Rayon }\end{array}$ & $\begin{array}{c}\text { Pulp Larut Bambu } \\
\text { Beema }\end{array}$ & $\begin{array}{c}\text { Pulp Larut Bambu } \\
\text { Industri }\end{array}$ \\
\hline Selulosa Alfa & $\%$ & Min. 94 & 96,63 & 95,09 \\
Derajat cerah & $\%$ ISO & Min. 88 & 88,18 & 88,01 \\
$\mathrm{~S}_{10}$ & $\%$ & Maks. 7,9 & 4,58 & 6,29 \\
$\mathrm{~S}_{18}$ & $\%$ & Maks. 4,9 & 0,87 & 1,8 \\
Abu tidak larut asam & $\mathrm{mg} / \mathrm{kg}$ & Maks. 100 & 98 & 99,5 \\
Kadar ekstraktif (DCM) & $\%$ & Maks. 0,2 & 0,06 & 0,07 \\
Kadar Abu & $\%$ & Maks. 0,15 & 0,07 & 0,09 \\
Viskositas (Intrinsik) & $\mathrm{mL} / \mathrm{g}$ & Min. 370 & 498 & 439 \\
Viskositas (Kuprietilendiamin) & $\mathrm{cP}$ & Min. 6,2 & 18,21 & 15,98 \\
\hline
\end{tabular}


Tabel 5. Hasil Analisis Kadar Nitrogen

\begin{tabular}{llccc}
\hline \multirow{2}{*}{ No. } & \multirow{2}{*}{ Jenis Pulp Larut } & \multicolumn{3}{c}{ Formula } \\
\cline { 3 - 5 } & & 1 & 2 & 3 \\
\hline 1. & Bambu Industri & 10,12 & 10,50 & 12,52 \\
2. & Bambu Beema & 11,18 & 12,57 & 12,97 \\
\hline
\end{tabular}

dikarenakan kadar selulosa alfa pulp larut bambu Beema lebih tinggi dari bambu Industri. Selulosa alfa ini diharapkan bereaksi dengan gugus nitril sehingga membentuk nitroselulosa. Perbandingan reagen pada formula 3 memberikan kadar nitrogen paling tinggi karena formula 3 memiliki kandungan air yang paling sedikit diantara ketiga formula tersebut, kandungan air tersebut didapatkan dari asam nitrat $65 \%$. Asam sulfat pada reaksi nitrasi berfungsi sebagai katalis dan dehydrating agent (mengikat air yang terbentuk) (Seta, Sugesty and Kardiansyah, 2014). Akan tetapi, jika katalis tersebut terlalu banyak, maka akan berubah menjadi inhibitor (pengotor) yang akan mengurangi rendemen proses nitrasi (JM Berg, Tymoczko, and Stryer L, 2002). Fenomena tersebut dapat dilihat pada perbandingan formula 1 dan formula 2, dimana pada formula 2 kadar nitrogennya lebih besar daripada formula 1 .

\section{Hasil Analisis Kelarutan Dalam Aseton Dan Ketidaklarutan Dalam Eter-Alkohol}

Hasil analisis ketidaklarutan nitroselulosa dalam aseton dapat dilihat di Tabel 6 dan ketidaklarutan dalam eter-alkohol dapat dilihat pada Tabel 7.

Analisis ketidaklarutan nitroselulosa dalam aseton dan eter-alkohol ini untuk memberikan gambaran dari proses nitrasi (distribusi kadar nitrogen). Kelarutan dalam eter-alkohol sangat penting (harus kurang dari 5\%) untuk beberapa jenis nitroselulosa (terutama untuk bahan baku propelan) (Vogelsanger and Sopranetti, 2010). Kelarutan dalam aseton hanya sebagai pendukung untuk penggunaan nitroselulosa tersebut. Ketidaklarutan nitroselulosa yang tinggi menunjukkan bahwa proses nitrasi belum sempurna dan distribusi kadar nitrogen belum merata. Pada pembuatan nitroselulosa tersebut hanya menggunakan pengadukan di awal proses nitrasi saja dengan batang pengaduk, sehingga sangat mungkin terjadi kadar nitrogen yang tidak homogen.
Tabel 6. Hasil Analisis Ketidaklarutan Nitroselulosa dalam Aseton

\begin{tabular}{clccc}
\hline \multirow{2}{*}{ No. } & $\begin{array}{l}\text { Jenis Pulp } \\
\text { Larut }\end{array}$ & \multicolumn{3}{c}{ Formula } \\
\cline { 2 - 5 } 1. & $\begin{array}{l}\text { Bambu } \\
\text { Beema }\end{array}$ & $7 \%$ & $2,31 \%$ & $2,27 \%$ \\
2. & $\begin{array}{l}\text { Bambu } \\
\text { Industri }\end{array}$ & $11,4 \%$ & $8,23 \%$ & $2,7 \%$ \\
\hline
\end{tabular}

Tabel 7. Hasil Analisis Ketidaklarutan Nitroselulosa dalam Eter-Alkohol

\begin{tabular}{llccc}
\hline \multirow{2}{*}{ No. } & $\begin{array}{l}\text { Jenis Pulp } \\
\text { Larut }\end{array}$ & \multicolumn{3}{c}{ Formula } \\
\cline { 2 - 5 } 1. & $\begin{array}{l}\text { Bambu } \\
\text { Beema }\end{array}$ & $7 \%$ & $7,77 \%$ & $6,63 \%$ \\
2. & $\begin{array}{l}\text { Bambu } \\
\text { Industri }\end{array}$ & $14,20 \%$ & $11,86 \%$ & $10,86 \%$ \\
\hline
\end{tabular}

\section{Uji Bakar Nitroselulosa}

Uji bakar nitroselulosa kedua jenis bambu pada ketiga jenis formula pada Tabel 8 menunjukkan hasil bahwa nitroselulosa dapat dibakar dengan cepat dan tanpa mengeluarkan asap. Ciri-ciri nitroselulosa adalah menghasilkan nyala api yang tidak meninggalkan sisa abu setelah dibakar, mengeluarkan asap yang sedikit (smokeless) dan terdapat percikan bunga api saat dinyalakan karena terdapat gugus nitro $\left(-\mathrm{NO}_{2}\right)$ pada nitroselulosa (Purnawan, 2010; Seta, Sugesty and Kardiansyah, 2014). Kandungan nitrogen pada nitroselulosa akan menurunkan energiaktivasi sehingga nitroselulosa mudah dibakar (Pourmortazavi et al., 2009). Akan tetapi kandungan silika pada nitroselulosa bambu Industri yang lebih tinggi dibandingkan nitroselulosa bambu Beema mengakibatkan abu sisa pembakaran nitroselulosa bambu industri lebih banyak.

\section{Pengujian FTIR Nitroselulosa}

Pengamatan terhadap spektrum inframerah nitroselulosa dari kedua jenis bambu menunjukkan perbedaan kurva FTIR antara nitroselulosa dan bahan baku. Nilai transmitant kurva FTIR pada Gambar 4 dan Gambar 5 mempunyai panjang gelombang yang paling besar sekitar $3444 \mathrm{~cm}^{-1}$ untuk kedua jenis nitroselulosa. Gambar 4 dan Gambar 5 juga menunjukkan gugus fungsi yang 
Tabel 8. Hasil Uji Bakar Nitroselulosa

\begin{tabular}{clccc}
\hline No. & Bahan Baku & Formula & Uji Bakar & Keterangan \\
\hline 1. & Bambu Beema & 1 & Terbakar & Tidak meninggalkan abu dan tidak berasap \\
2. & Bambu Beema & 2 & Terbakar & Tidak meninggalkan abu dan tidak berasap \\
3. & Bambu Beema & 3 & Terbakar & Tidak meninggalkan abu dan tidak berasap \\
4. & Bambu Beema & Pulp larut & Terbakar & Meninggalkan abu dan berasap \\
5. & Bambu Industri & 1 & Terbakar & Meninggalkan abu sedikit dan tidak berasap \\
6. & Bambu Industri & 2 & Terbakar & Meninggalkan abu sedikit dan tidak berasap \\
7. & Bambu Industri & 3 & Terbakar & Meninggalkan abu sedikit dan tidak berasap \\
8. & Bambu Industri & Pulp larut & Terbakar & Meninggalkan abu dan berasap \\
\hline
\end{tabular}

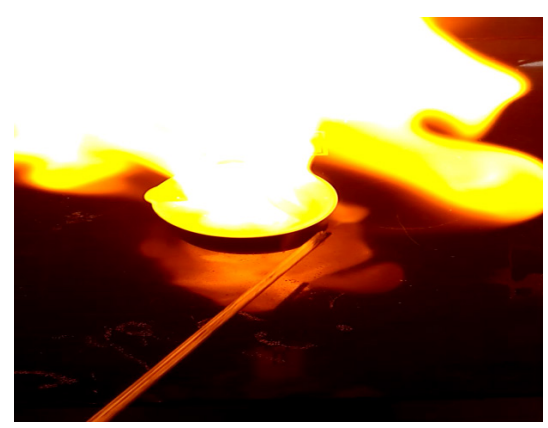

Nitroselulosa Bambu Beema

Gambar 1. Uji Bakar Nitroselulosa

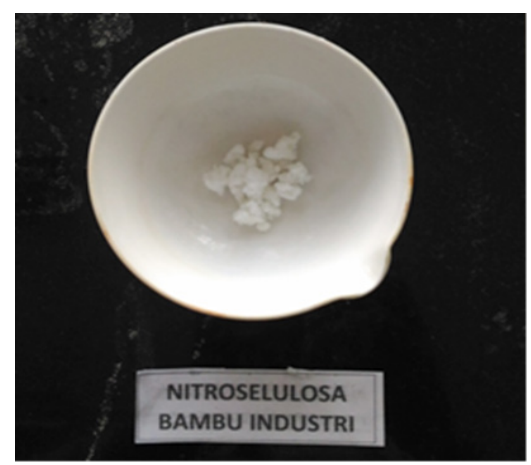

a

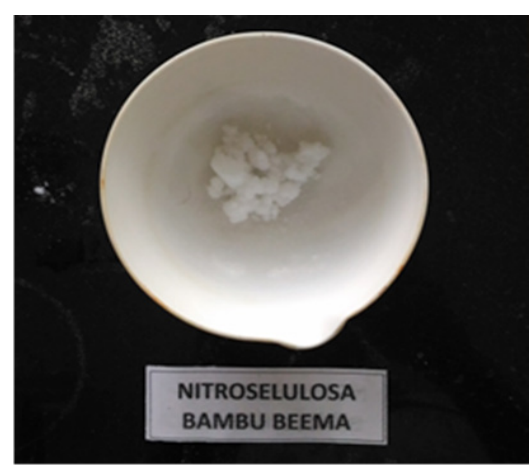

c

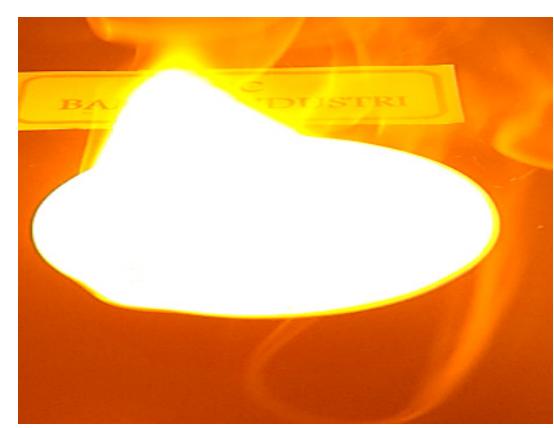

Nitroselulosa Bambu Industri

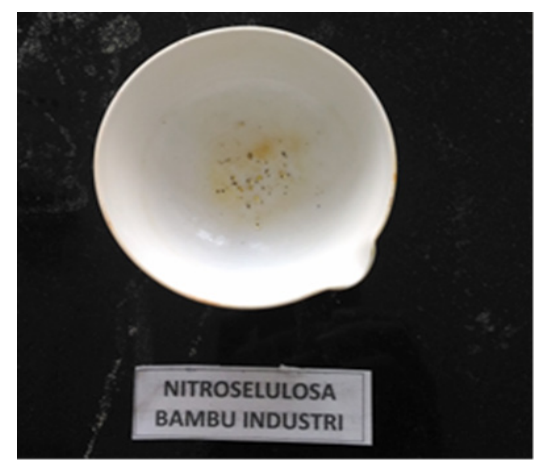

b

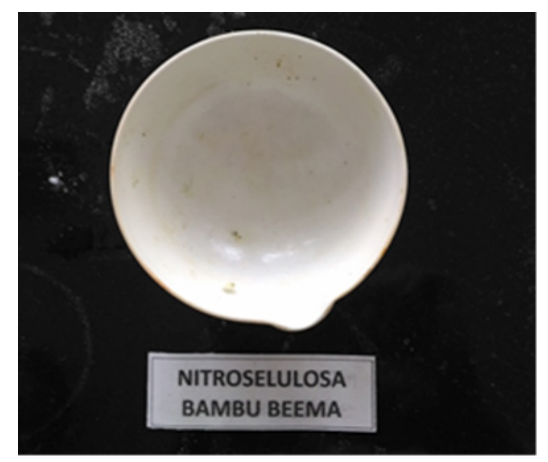

d

Gambar 2. Nitroselulosa Sebelum Uji Bakar (A dan C) dan Setelah Uji Bakar (B dan D) 


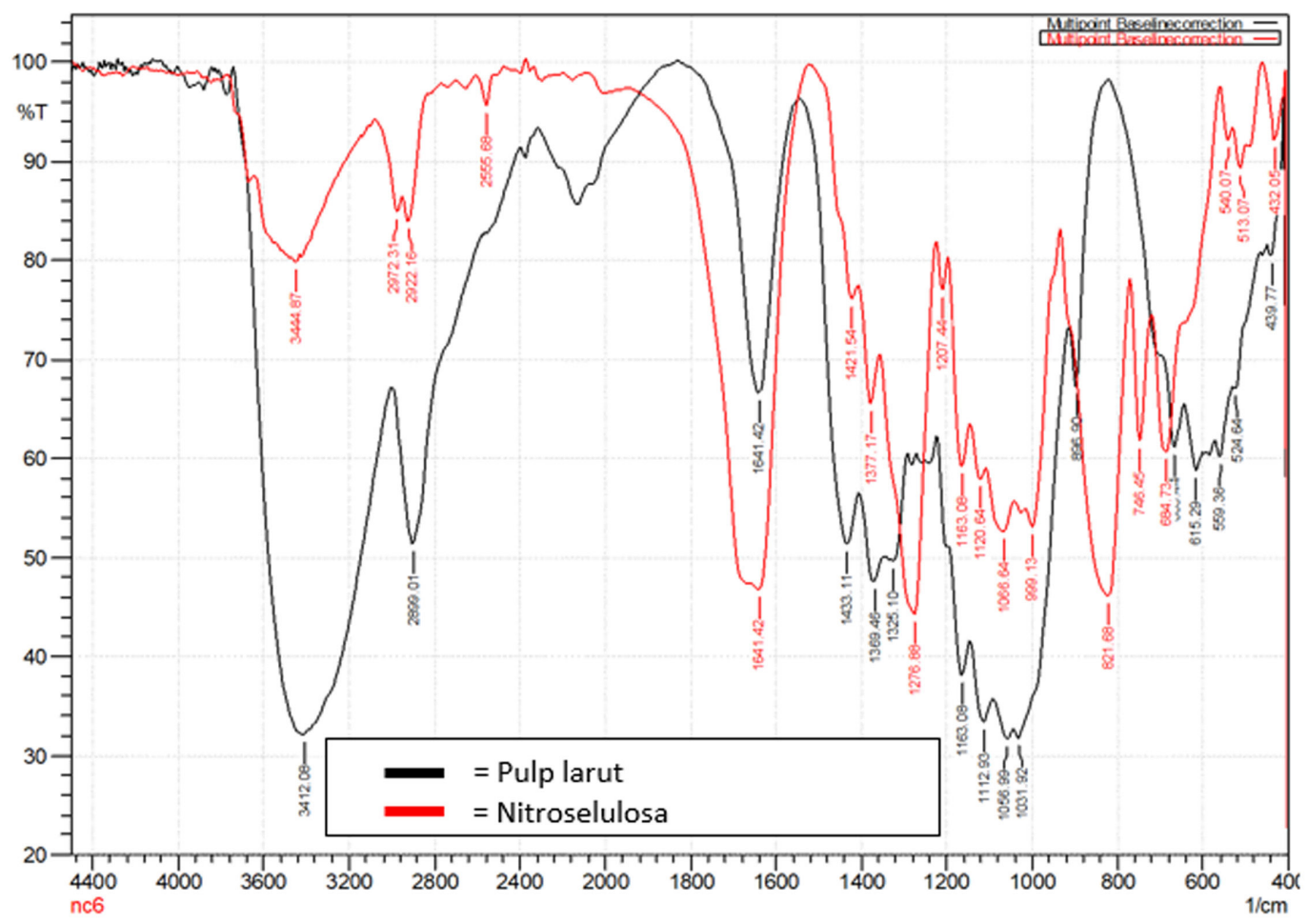

Gambar 3. Spektrum FTIR Nitroselulosa dan Pulp larut Bambu Industri

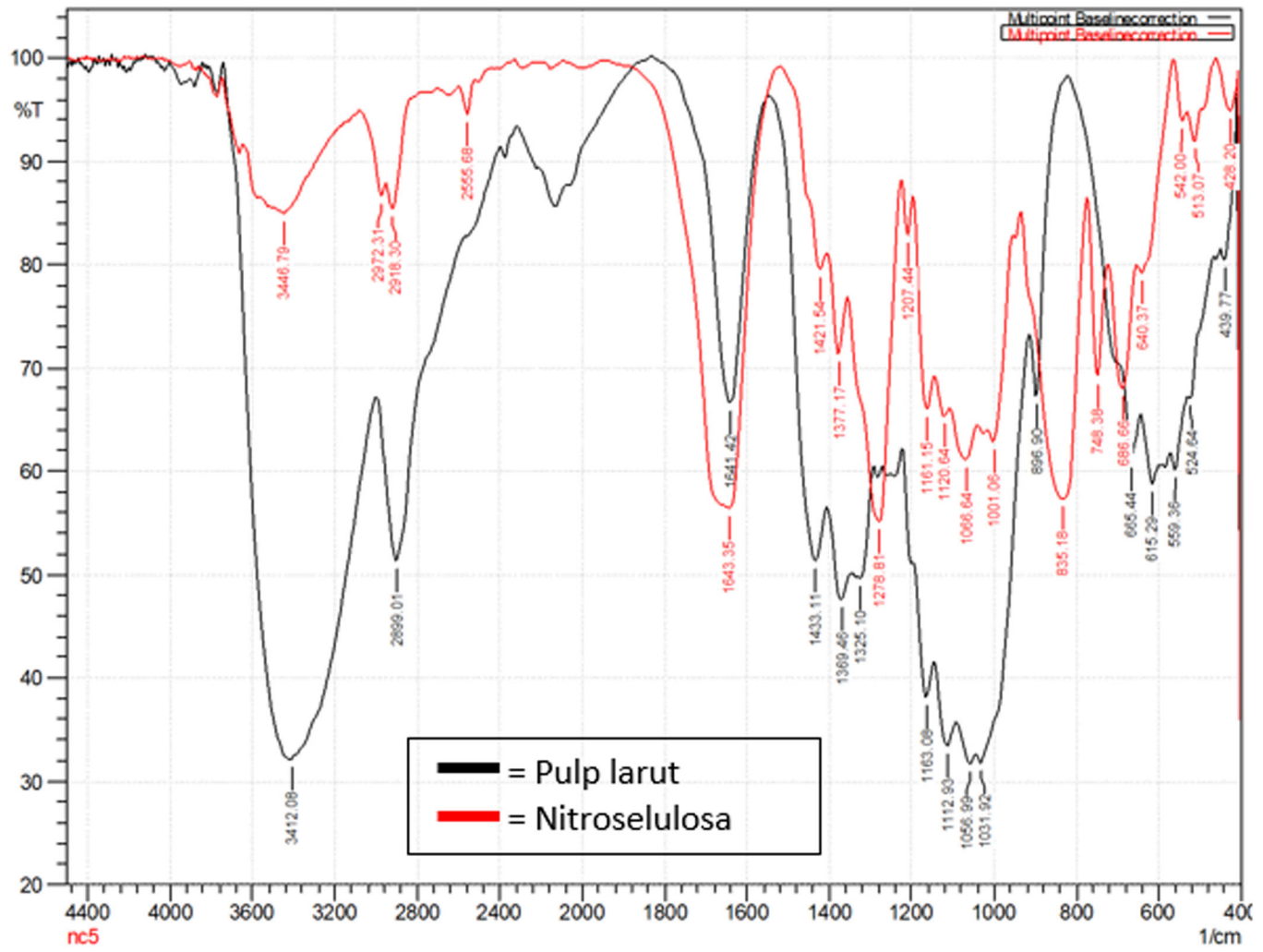

Gambar 4. Spektrum FTIR Nitroselulosa dan Pulp Larut Bambu Beema 
spesifik pada nitroselulosa, yaitu pada panjang gelombang sekitar $1600 \mathrm{~cm}^{-1}$ R-O-NO, 1400 $\mathrm{cm}^{-1} \mathrm{R}-\mathrm{NO}_{2}$ dan, $600 \mathrm{~cm}^{-1} \mathrm{R}-\mathrm{NO}_{2}$ atau R-O-NO (Seta, Sugesty and Kardiansyah, 2014). Panjang gelombang tersebut menunjukkan adanya gugus nitril dimana pada nitroselulosa menggantikan gugus hidroksil. Gugus nitril yang terdapat pada nitroselulosa juga mengindikasikan bahwa telah terjadi proses nitrasi.

\section{Kesimpulan}

Nitroselulosa yang dibuat dari pulp larut bambu Beema dengan formula 3 (perbandingan $\mathrm{HNO}_{3}: \mathrm{HNO}_{3}$ Fuming: $\left.\mathrm{H}_{2} \mathrm{SO}_{4}=1: 1: 1,6\right)$ memberikan kadar nitrogen yang paling tinggi diantara nitroseluosa yang lain. Nitroselulosa dari pulp larut bambu Beema dan Industri dengan formula 3 berdasarkan kadar nitrogen sudah bisa memenuhi kualifikasi sebagai bahan baku propelan. Analisis kualitatif yang dilakukan pada kedua jenis nitroselulosa tersebut juga mendukung kualifikasi nitroselulosa tersebut. Akan tetapi nilai kelarutan dalam eter-alkohol dan dalam aseton kedua jenis nitroselulosa tersebut menunjukkan bahwa kualitas proses nitrasinya masih belum baik sehingga perlu dilakukan perbaikan pada sisi proses produksi nitroselulosa sehingga dapat digunakan sebagai bahan baku pembuatan propelan.

\section{Daftar Pustaka}

Chen, C. et al. (2016) 'Cellulose (Dissolving Pulp) Manufacturing Processes and Properties: A Mini-Review', BioResources, 11(2), pp. 5553-5564.

Chen, H. (2014) Biotechnology of Lignocellulose: Theory and Practice. Springer. doi: 10.1007/978-94-007-6898-7.

Fallah, F., Khorasani, M. and Ebrahimi, M. (2018) 'Factors affecting the properties of nitrocellulose emulsions: A comparative study', Carbohydrate Polymers. Elsevier Ltd., 189, pp. 267-272. doi: 10.1016/j. carbpol.2017.11.002.

Granström, M. (2009) Cellulose Derivatives : Synthesis, Properties and Applications. University of Helsinki.

https://kemenperin.go.id (Indonesia Kurang Bahan Baku Tekstil) (no date).
Kim, D. H. (2014) 'Nitrocellulose', in Wexler, P. (ed.) Encyclopedia of Toxicology. 3rd Editio. Academic Press, p. 5220. doi: 10.1016/ B978-0-12-386454-3.00043-9.

Miranda and Fani, R. (2013) 'Pembuatan Nitroselulosa dari Selulosa- $\alpha$ Pelepah Sawit dengan Variasi Waktu Nitrasi dan Rasio Bahan Baku Terhadap Asam Penitrasi', (November), pp. 240-250.

Patrick, K. (2011) 'The Dissolving Pulp Gold Rush', Paper360, p. 8.

Pourmortazavi, S. M. et al. (2009) 'Effect of nitrate content on thermal decomposition of nitrocellulose', Journal of Hazardous Materials, 162(2-3), pp. 1141-1144. doi: 10.1016/j.jhazmat.2008.05.161.

Pramunditta, B. E. et al. (2012) 'Pembuatan Nitroselulosa dari Kapas (Gossypium sp.) dan Kapuk (Ceiba pentandra) Melalui Reaksi Nitrasi', Jurnal Teknik ITS, 1(1), pp. F41F46. doi: 10.12962/j23373539.v1i1.504.

Purnawan (2010) 'Optimasi Proses Nitrasi pada Pembuatan Nitro Selulosa dari Serat Limbah Industri Sagu', Jurnal Rekayasa Proses, 4(2), pp. 30-34.

Saragih, E., Padil, P. and Yelmida, Y. (2014) 'Pembuatan Nitroselulosa Dari Selulosa Hasil Pemurnian Pelepah Sawit dengan Hidrogen Peroksida (H2O2) Sebagai Bahan Baku Pembuatan Propelan', Jurnal Online Mahasiswa Fakultas Teknik Universitas Riau (JOM FT UNRI), 1(1).

Seta, F. T., Sugesty, S. and Kardiansyah, T. (2014) 'Pembuatan Nitroselulosa dari Berbagai Pulp Larut Komersial sebagai Bahan Baku Propelan', Pembuatan Nitroselulosa dari Berbagai Pulp Larut Komersial, 4(02), pp. 97-106.

Sugesty, S. (2014) Dissolving Pulp dari Bambu Beema dan Bambu Industri sebagai Bahan Baku Serat Rayon Viskosa. Bandung (unpublished).

Sugesty, S., Kardiansyah, T. and Hardiani, H. (2015) 'Bamboo as raw materials for dissolving pulp with environmental friendly technology for rayon fiber', Procedia Chemistry ScienceDirect 3 rd International Seminar on Chemistry, 17, pp. 194-199. doi: 10.1016/j.proche.2015.12.122.

Vogelsanger, B. and Sopranetti, R. (2010) Testing of Nitrocellulose. STANAG 417. NITROCHEMIE.

Wibowo, H. B. (2007) 'Potensi Pabrikasi Propelan Homogen di Indonesia', Berita Dirgantara, 8(1), pp. 1-5. 